\title{
Citrus Blackfly Parasitoid, Amitus hesperidum Silvestri (Insecta: Hymenoptera: Platygasteridae) ${ }^{1}$
}

Ru Nguyen ${ }^{2}$

\section{Introduction}

Amitus hesperidum Silvestri is one of the most effective parasites of the citrus blackfly, Aleurocanthus woglumi Ashby. This parasite was described by Silvestri in 1927 from Aleurocanthus citriperdus in Hong Kong and Singapore (Silvestri 1927). It was collected in India and introduced into Mexico for controlling citrus blackfly (Smith et al. 1964). Because of the success in Mexico, it was imported into Texas (Summy et al. 1983) and Florida (Hart et al. 1978) to suppress the population of citrus blackfly in these states.

\section{Distribution}

Amitus hesperidum has been reported as native to Asia. It is found in Sri Lanka, China (Hong Kong, Szechuen), India, Java, Malaya, Pakistan, and has been introduced into Guam, Venezuela, Mexico, and the United States (Florida and Texas) to control citrus blackfly (Silvestri 1927, Smith et al. 1964, Flanders 1969). In Florida, it was released in Brevard, Broward, Collier, Dade, Highlands, Hillsborough, Indian River, Lee, Manatee, Martin, Monroe,
Okeechobee, Palm Beach, Pinellas, Sarasota and St. Lucie counties.

\section{Description}

Female shiny black, tiny ( $0.75 \mathrm{~mm}$ long). Antenna $0.65 \mathrm{~mm}$ long, 10 segments with the last three closely united and forming a club; wings shiny; hind tarsus 5-segmented. Male similar to female, antenna ten-segmented filiform, scape curved, with all flagellar joints longer than wide and covered with short erect hairs (Silvestri 1927).

\section{Biology}

This species is non-polyembryonic and biparental in reproduction with a sex ratio of 1:1. It lays eggs in all three larval stages of the host, with a preference for the first stage. A female of the citrus blackfly usually produces two, three or occasionally four adult parasites, whereas a male host pupa produces only one. Both male and female parasites can be produced from a female of the citrus blackfly pupa. Amitus hesperidum females have a life span of four to five days, and males live three to four days. Life cycle from egg to adult varies from 45 to 60 days

1. This document is EENY-243 (originally published as DPI Entomology Circular 311), one of a series of Featured Creatures from the Entomology and Nematology Department, Florida Cooperative Extension Service, Institute of Food and Agricultural Sciences, University of Florida. Published: October 2001. This document is also available on Featured Creatures Website at http://creatures.ifas.ufl.edu. Please visit the EDIS Website at http://edis.ifas.ufl.edu and the Entomology and Nematology Department website at http://entnemdept.ifas.ufl.edu/. 2. Ru Nguyen, Florida Department of Agriculture and Consumer Services, Division of Plant Industry, Gainesville, FL.

The Institute of Food and Agricultural Sciences (IFAS) is an Equal Employment Opportunity - Affirmative Action Employer authorized to provide research, educational information and other services only to individuals and institutions that function without regard to race, creed, color, religion, age, disability, sex, sexual orientation, marital status, national origin, political opinions or affiliations. For information on obtaining other extension publications, contact your county Cooperative Extension Service office. Florida Cooperative Extension Service / Institute of Food and Agricultural Sciences / University of Florida / Larry R. Arrington, Interim Dean 


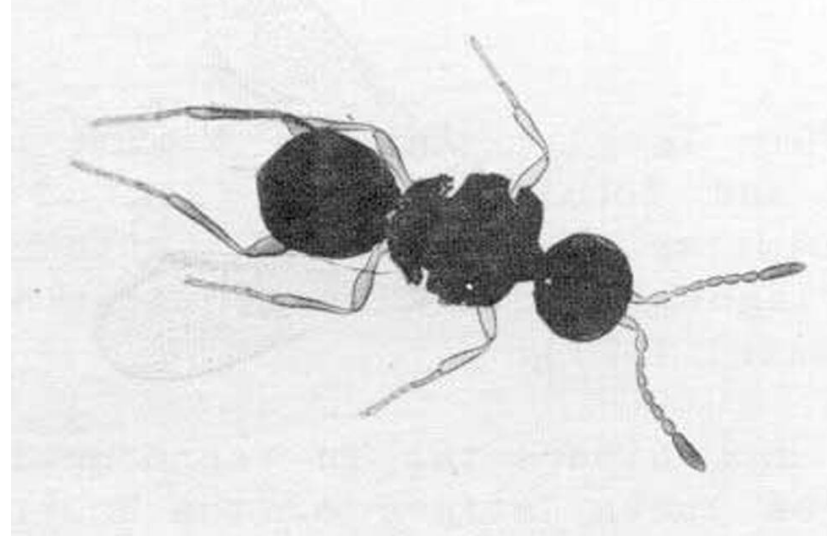

Figure 1. Adult female Amitus hesperidum Silvestri, a parasitoid of the citrus blackfly. Credits: Division of Plant Industry

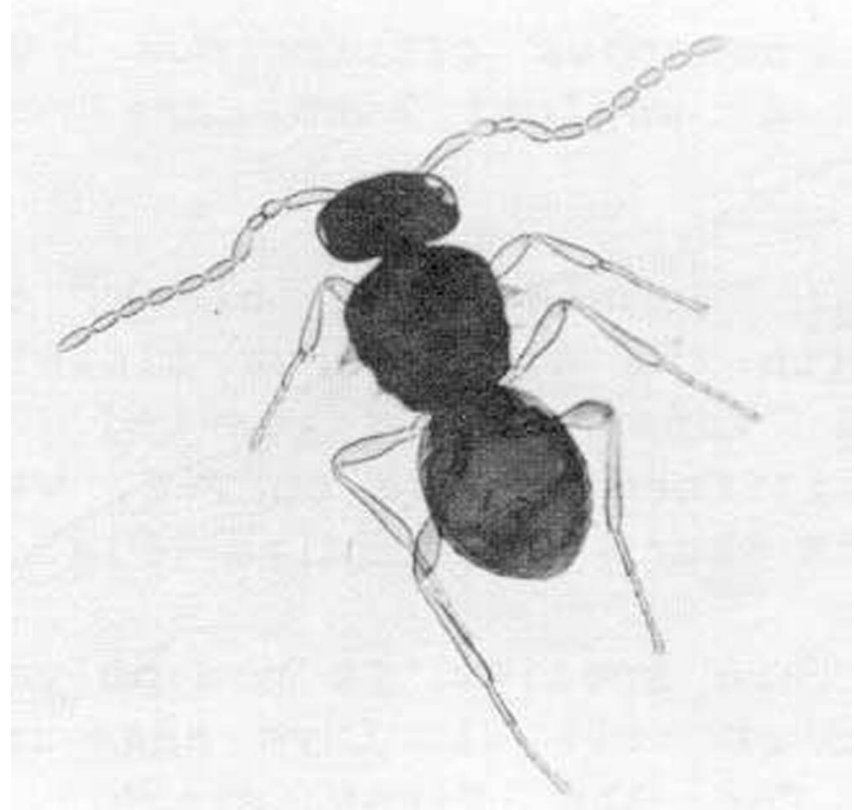

Figure 2. Adult male Amitus hesperidum Silvestri. Credits: Division of Plant Industry

under laboratory condition $\left(\mathrm{T}=27^{\circ} \mathrm{C}\right)$. In the field, A. hesperidum is well synchronized with the host and has a high rate of reproduction. A female can produce more than 60 offspring; it is very effective with the high density of the citrus blackfly in Florida. However, the female has a poor searching capability and survives only four to five days under field conditions. The parasite population will die out soon after suppressing A. woglumi populations (Flander 1969, Nguyen et al. 1983).

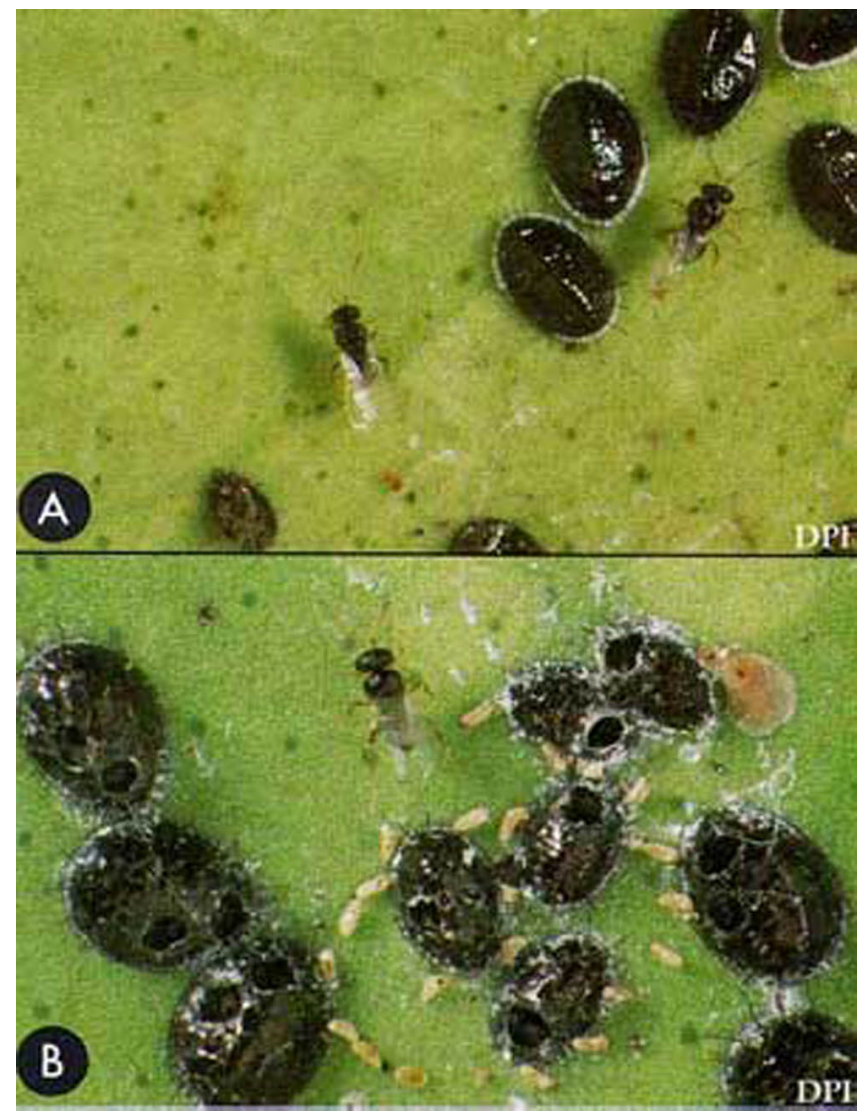

Figure 3. Amitus hesperidum parasitoids (A) adults near healthy pupae; (B) adult with empty pupal cases of citrus blackfly, Aleurocanthus woglumi Ashby, from which adult parasitoids have emerged. Credits: Division of Plant Industry

\section{Hosts}

Aleurocanthus citriperdus Quaintance and Baker, A. spiniferus (Quaintance), and A. woglumi Ashby are reported as hosts (Silvestri 1927, Smith et al. 1964).

\section{Selected References}

Flanders SE. 1969. Herbert D. Smith's observations on citrus blackfly parasites in India and Mexico and the correlated circumstances. Canadian Entomologist 101: 467-480.

Hart WG, Selhime A, Harlan DP, Ingle SJ, Sanchez RM, Rhode RH, Garcia CA, Caballero J, Garcia RL. 1978. The introduction and establishment of parasites of citrus blackfly, Aleurocanthus woglumi in Florida (Hemiptera: Aleyrodidae). Entomophaga 23: 361- 366. 
Nguyen Ru, Brazzel JR, Poucher C. 1983.

Population density of the citrus blackfly, Aleurocanthus woglumi Ashby (Homoptera:

Aleyrodidae), and its parasites in urban Florida in 1979-81. Environmental Entomology 12: 878-884.

Silvestri F. 1927. Contribuzione alla conoscenza degli Aleurodidae (Insecta: Hemiptera) viventi su citrus in Estremo Oriente e dei loro parassiti. Boll. Lab. Zool. Portici. 21: 1-60.

Smith HD, Maltby HL, Jimenez EJ. 1964. Biological control of the citrus blackfly in Mexico. U.S. Department of Agriculture Technical Bulletin 1311: 1-30.

Summy KR, Gilstrap FE, Hart WG, Caballero JM, Saenz I. 1983. Biological control of citrus blackfly (Homoptera: Aleyrodide) in Texas. Environmental Entomology 12: 782-796. 